Mariusz Mohyluk

\title{
РАБОТА КОДИФИКАЦИОННОЙ КОМИССИИ ІІ РЕЧИ ПОСПОЛИТОЙ НАД РЕФОРМОЙ ПРОКУРАТУРЫ
}

\section{1. Вводные замечания}

В восстановленном в ноябре 1918 г. польском государстве по-прежнему функционировали отдельные правовые системы стран, захвативших польские земли после разделов (австрийская, немецкая, французская, российская, венгерская - Орава и Спиш). Вопрос упорядочения системы правосудия выдвинулся на первый план при образовании фундаментальных основ II Речи Посполитой и стал самой неотложной политической и общественной проблемой. Её решением занялось тогдашнее поколение польских юристов. Во II Речи Посполитой работа над ней была поручена учрежденной специально с этой целью кодификационной комиссии.

Кодификационная комиссия Речи Посполитой (далее по тексту - КK) образованная на основе закона, принятого Законодательным сеймом 3 июня $1919 \mathrm{r}$. ${ }^{1}$ представляла собой государственное учреждение, главной задачей которого была „подготовка проектов единого законодательства для всех земель, входящих в состав государства". Относительно закона об устройстве общих судов (в том числе, и прокуратуры), то реализацию этой задачи взяла на себя учре-

Dz. P.P. P. z 6.VI.1919 r., № 44, ст.315. к важнейшим публикациям на тему кодификационной комиссии во II Речи Посполитой принадлежат: S. Grodziski, Komisja Kodyfikacyjna Rzeczypospolitej Polskiej „Czasopismo Prawno-Historyczne” 1981, z.1 с. 47 и сл..; A. Lityński, Wydział Karny Komisji Kodyfikacyjnej II Rzeczypospolitej. Dzieje prac na częścią ogólną kodeksu karnego, „Prace naukowe Uniwersytetu Śląskiego w Katowicach" Katowice 1991, № 1172.; L. Górnicki, Prawo cywilne w pracach Komisji Kodyfikacyjnej Rzeczypospolitej Polskiej w latach 1919-1920; K. Sójka-Zielińska, Organizacja prac nad kodyfikacją prawa cywilnego w Polsce międzywojennej, „Czasopismo Prawno-Historyczne” 1975, z.2, с. 271 и сл..; Z. Szcząska: Minister Sprawiedliwości jako uczestnik procesu legislacyjnego (w:) Tworzenie prawa w Polsce..., с. 69 и сл.; R. Kraczkowski: Aparat legislacyjny rządu w II Rzeczypospolitej, PiP 1982, z. 7, с. 85 и сл.; W.M. Bartel: Udział przedstawicieli środowisk akademickich w pracach Komisji Kodyfikacyjnej RP (1919-1939), „Krakowskie Studia Prawnicze” 1990, r. 23, с. 177 и сл.; M. Pietrzak: Z problematyki kodyfikacji prawa w II Rzeczypospolitej (w:) Partykularyzm a unifikacja prawa w Polsce (XV-XX w.), Gdańsk 1994, с. 61 и сл.; M. Mohyluk: Porządkowanie prawa w II Rzeczypospolitej: Komisja Kodyfikacyjna i Rada Prawnicza, „Czasopismo Prawno-Historyczne” 1999, z. 1-2, с. 285 и сл. 
жденная в 1920 г. Подкомиссия по устройству судебной системы кодификационной комиссии. Параллельно с ней такую же работу начало также Министерство юстиции. Важным звеном в этом мероприятии был Сейм, который, принимая мартовскую конституцию вместе с принципами судоустройства, указал вышеуказанным организациям определенное направление действий.

\section{2. Система органов и учреждений прокуратуры до унификации}

\section{1. Органы и учреждения прокуратуры в бывшем королевстве Польском}

Впервые об органах и учреждениях прокуратуры польские власти решали во Временных положениях о судоустройстве в королевстве Польском, изданных в 1917 г. Департаментом юстиции Временного государственного совета. ${ }^{2}$ В вышеуказанном нормативном правовом акте эти органы были определены как один из органов судебной системы, они именовались королевско-польскими и осуществляли свою деятельность от имени короны королевства Польского. В ІІІ главе, озаглавленной Публичное учреждение, прокуроры были представлены как публичные должностные лица. Обязанности генерального прокурора исполнял Директор Департамента юстиции, при Верховном суде соответствующее количество прокуроров, а при апелляционном и окружном судах - прокурор совместно с соответствующим количеством подпрокуроров. Эти должности могли занимать только лица „с безупречной репутацией”, обладающие гражданством королевства Польского (ст. 13). Прокуроров всех судов и подпрокуроров апелляционного суда должен назначать Маршалок великий коронный по заявлению Директора Департамента юстиции (ст. 20). Подпрокуроров окружного суда и секретарей прокурорских учреждений назначал только вышеупомянутый Директор по заявлению председателей или прокуроров соответствующих судов (ст.21). ${ }^{3}$ Все прокуроры (это касалось также судей) назначались на неопределенное время, а увольнение их с должности зависело от власти, которая их назначила (ст. 15). Прокуроры (но не подпрокуроры) как ор-

2 Dz. Urz. Dep. Spr. TRS № 1. См. также R.A. Stefański: Prokuratura II Rzeczypospolitej, „Przegląd Sądowy”1992, № 5-6, c. 70-85.; M. Materniak-Pawłowska, Ustrój sądownictwa powszechnego II Rzeczypospolitej, Poznań 2003; M. Mohyluk, Prawo o ustroju sądów powszechnych w pracach Komisji Kodyfikacyjnej II Rzeczypospolitej, Białystok 2004; J. Szarycz: Sędziowie i sądy w Polsce, Ministerstwo Sprawiedliwości, Warszawa 1988.S. Włodyka, Organizacja wymiaru sprawiedliwości (w:) Historia państwa i prawa, t. V, cz. II, rozdz. VIII pod. red. F. Ryszki, Warszawa 1968, с. 7-54.

Прокуроры и подпрокуроры давали перед назначающим их лицом торжественную клятву соответственно следующей роте: „Перед лицом Всемогущего Господа Бога клянусь, что на порученной мне служебной должности буду способствовать изо всех сил, в пределах моих действий, укреплению свободы, независимости и могущества Речи Посполитой Польши, которой всегда буду верно служить: всех граждан страны уважать буду в равной степени, строго соблюдая положения закона, обязанности на моем посту буду выполнять добросовестно, распоряжения моих начальников - выполнять тщательно, а служебную тайну сохранять. Помоги мне Господи Боже". 
ганы Департамента юстиции занимались вопросами администрации правосудия (ст. 16). Прокурорами Верховного суда могли быть назначены лица, отличающиеся теоретическим и практическим знанием законов (ст. 17). Остальные кандидаты на должности прокуроров и подпрокуроров должны обладать юридическим образованием и соответствующими практическими знаниями действующего законодательства, приобретенными во время прохожденния судебной практики [aplikacji] (ст. 18).

Следует помнить, что вышеуказанные законы, касающиеся учреждений и органов прокуратуры, постепенно, начиная с 1918 года, изменялись - отменялись и модифицировались - приспосабливаясь, в последовательном порядке, к реалиям и правопорядку формирующейся II Речи Посполитой ${ }^{4}$.

Более подробное определение должности прокурора содержала Инструкция для органов и учреждений прокуратуры от 1 марта 1918 г. ${ }^{4}$ В ней подчеркивалось, что органы и учреждения прокуратуры должны соблюдать принцип законности правосудия и способствовать этому с помощью мер, указанных в российских процедурах (гражданского и уголовного судопроизводства).

Подводя итоги сказанному, следует отметить, что польская организация прокурорских органов и учреждений еще до унификации, на территории, аннексированной раньше Россией, заключалась в иерархическом подчинении нижестоящих вышестоящим по точно определенным степеням, как в области отдельных прокурорских действий, так и в области организационных, административных распоряжений внутри органов и учреждений. Самостоятельность прокурора в пределах закона была заметна лишь во время выступления перед судами. ${ }^{5}$ Указанные нормативные правовые акты называли следующие прокурорские посты:

1) Министр юстиции - исполняющий обязанности Генерального прокуpopa,

2) прокуроры Верховного суда - один из них был назначен ,первым прокурором", как глава прокуратуры при Верховном суде; такой прокурор непосредственно подчинялся Министру юстиции и замещал его во всех судебных действиях, требующих явки прокурора в Верховном суде,

3) апелляционные прокуроры - непосредственно подчиненные Министру юстиции, вышестоящие должностные лица по отношению ко всем прокурорским органам и учреждениям при апелляционном суде,

4 Dz. Urz. Min. Spraw. № 9, ст. 21.

5 S. Gołąb: Ustrój sądów powszechnych, Warszawa 1929, c. 49-51. 
4) окружные прокуроры - непосредственно подчиненные апелляционному прокурору,

5) подпрокуроры - при всех прокуратурах; выполняли обязанности, возложенные на них прокурорами, и замещали их в зависимости от потребностей соответственно предоставленным полномочиям.

На так наз. „восточные территории”, по мере развития военных событий, распространялось действие польского законодательства, посредством специальных актов: приказов, распоряжений, декретов. ${ }^{6}$

\section{2. Прокуроры на территории, аннексированной раньше Австрией}

В округах апелляционных судов: краковском и львовском, в период до унификации закона об устройстве общих судов, действовал по-прежнему австрийский Организационный судебный закон от 27 ноября 1896 г. и вместе с ним распоряжение Министра юстиции от 5 мая 1897 г., вводящее судебную инструкцию и ряд других нормативных правовых актов. Однако они не содержали организационных положений по отношению к прокуратуре, так как их основной блок находился в австрийском Законе об уголовном судопроизводстве от 23 мая 1873 г. В главе III этого закона, О Прокуратории государства (§ 29 - § 37), при каждом трибунале I инстанции был установлен прокурор государства (Staatsanwalt), при каждом трибунале II инстанции - старший прокурор (Oberstaatsanwalt), а при Верховном суде, как кассационном трибунале - генеральный прокурор (Generalprocurator) с соответствующим количеством (трех) заместителей - генеральных адвокатов (§ 29). При повятовых судах работали так наз. сотрудники прокуратории и их заместители, выполняющие обязанности публичных обвинителей.7 Члены прокуратории государства должны были, в пределах предоставленных им компетенций, защищать интересы государства. В своих действиях они не зависели от судов, при которых функционировали. Прокуроры государства при трибуналах I инстанции подчинялись старшим прокурорам, те же, в свою очередь, так же, как и генеральный прокуpop, уже непосредственно Министру юстиции (§ 30). Таким образом, вышеуказанные положения регулировали принципы (внутренней и внешней) организации прокуратории в австрийском уголовном процессе. ${ }^{8}$ Внешняя структура, несомненно, обращалась в своих важнейших предположениях к французскому

Распоряжение Генерального комиссара Восточных земель о urządzeniu ogólnego sądownictwa na obszarach wschodnich podlegających Komisarzowi Gen. Ziem Wschodnich от 15 мая 1919 r.; Приказ военачальника польских войск w przedmiocie organizacji wymiaru sprawiedliwości na terenach przyfrontowych i etapowych от 15 октября 1920 r.; декрет военачальника войск Центральной Литвы w przedmiocie organizacji wymiaru sprawiedliwości na terytorium Litwy Środkowej от 18 ноября 1920 г. Вышеуказанные нормативные акты были частично изменены на основе распоряжений СМ от 19 января и 19 июня 1922 г. - Dz.U. RP № 10, ст.70 и № 47, ст. 414.

7 J. Makarewicz: Ustawa o postępowaniu karnym, Kraków 1911, c. 52-60.

8 P. Stebelski: Komentarz do austriackiego postępowania karnego, Lwów 1901, c. 52-66. 
законодательству. Глядя на её внутренний порядок можно было заметить, что характеризовался он единством и нераздельностью, подкрепленными принципом иерархии и централизма. В обсуждаемом учреждении, в отличие от суда, был исключен инстанционный порядок. Распоряжение, выданное представителем прокурорского органа, обязывало всех прокуроров и его решение не могло быть изменено, напр. посредством обращения к вышестоящей власти с жалобой на данное решение. Главным принципом в деятельности прокуратории государства по австрийскому процессуальному праву был принцип легализма в противоположность французскому принципу утилитаризма. ${ }^{9}$ Закон об уголовном судопроизводстве устанавливал также пределы взаимной независимости прокуратории государства и судов. Обе организации, в рамках своей деятельности, были независимы, автономны и равноправны. Эти отношения иногда нарушались во время процесса, когда прокуратория государства выступая в роли стороны, формально подчинялась судам, особенно в момент рассмотрения процессуальных заявлений. ${ }^{10}$

Существенная модификация, имеющая, скорее всего, приспособленческий и унифицирующий характер в организации этого органа правосудия произошла 8 февраля 1919 г. на основании декрета. Таким образом, изменения в структуре и номенклатуре в отдельных инстанциях судебной системы нашли также свое отражение в пределах бывшей австрийской прокуратории государства.

Напомним, что функции Верховного судебного и кассационного трибунала в Вене перенял на себя в 1919 г. Верховный суд в Варшаве, что обозначало присоединение австрийской прокуратуры и её подчинение, по крайней мере, в отношении иерархии, то есть, подчиненности, служебной и административной зависимости, польскому аппарату государственной власти. Прежние окружные и краевые суды (трибуналы I инстанции) были заменены однородными окружными судами, а суды II инстанции (высшие краевые суды в кракове и Львове) - апелляционными судами, при которых, по-прежнему, функционировали прокуратуры. Согласно ст. 8 декрета, общей администрацией судов в своем округе руководил председатель апелляционного суда в рамках полномочий, предоставленных ему Министром юстиции или законом. Те же принципы - по мнению С. Голомба - распространялись также на действия прокурора при апелляционном суде по порученным ему административным делам. ${ }^{11}$ Итак, после этих изменений во II Речи Посполитой до 1928 г., на тер-

\footnotetext{
9 Там же, с. $55-56$.

10 П. Стебельски в своем Комментарии установил, что до 1901 закон об организации прокуратории государства в Австрии не был издан. По-прежнему обязывало распоряжение министра юстиции от 3 августа 1854 г. о внутренней структуре и порядке действий государственной прокуратории и общая инструкция для всех старших прокураторий от 25 ноября 1873 г. 
риториях, ранее аннексированнызх Австрией, функционировали окружные и аппеляционные прокуроры (два). Иерархически, по существу и формально они подчинялись Первому прокурору при Верховном суде, затем Министру юстиции, исполняющему обязанности Генерального прокурора.

\section{3. Прокуратура в бывшей прусской провинции}

Об организации и задачах прокуратуры на территории бывшей прусской провинции II Речи Посполитой еще до введения единого законодательсва об устройстве общих судов говорилось в главе Х. Прокуратура (§ 142 - § 153) немецкого закона об устройстве судебной системы от 27 января 1877 г. В изменяемом и пополняемом с 1919 г. польскими властями нормативном правовом акте $^{12}$, в $\$ 142$ устанавливалось, что при каждом суде должна быть учреждена прокуратура. Посты в ней занимали:

1) при Верховном суде в Варшаве соответствующее количество прокуроров и подпрокуроров; один из прокуроров был назначен на должность Первого прокурора ${ }^{13}$,

2) при апелляционных, окружных судах и судах с участием присяжных заседателй один или больше прокуроров; если в состав суда входило несколько сотрудников прокуратуры, тогда один из них был назначен на должность первого сотрудника прокуратуры а остальные были его заместителями ${ }^{14}$,

3) при повятовых судах и судах с участием заседателей (мировых судах) один или больше сотрудников подпрокуратуры; в случае необходимости была допущена возможность учреждения подпрокуратуры при одном из повятовых судов, но общей для нескольких повятовых судов и судов с участием заседателей (мировых судов), принадлежащих к одному судебному округу (§ 143).

Сотрудники прокуратуры при апелляционных и окружных судах имели право - во всех судах своего округа - самостоятельно выполнять свои обязанности. Сотрудникам подпрокуратуры при повятовом суде такое право принадлежало только при повятовых судах и судах с участием заседателей (мировых судах; § 146). Прокуроры должны были выполнять служебные распоряжения своего начальника. Надзор и руководство было возложено, главным образом,

12 Единый текст закона с учетом этих изменений был опубликован в распоряжении Министра юстиции от 16 июня 1922 r. - Dz.U.RP № 46, ст. 390.

13 По упомянутой выше ст. 17 закона об организации временного управления б. прусской провинции от 1 июля 1919 г. (Dz.Pr.R.P. nr 64, poz. 385) существующие до сих пор атрибуции Суда Рейха перешли на Верховный суд в Варшаве.

14 В распоряжении от 15 декабря 1919 г. (Tygodnik urzędowy № 70) говорилось о подппрокурорах при окружных судах а в распоряжении от 31 января 1920 г. (Dz. Urz. Min. b. dzielnicy pruskiej № 6) о назначении так наз. комисорийных подпрокуроров [podprokuratorów komisoryjnych] при окружных судах. 
как это формулировалось в законе § 148, на „управление справедливости”, то есть, Министерство юстиции по отношению ко всем сотрудникам прокуратуры. Вышеупомянутый объем компетенции был оставлен, в свою очередь, для первых сотрудников прокуратуры по отношению ко всем сотрудникам прокуратуры своего округа. На должности прокуроров при окружном и апелляционном судах могли назначаться лица, обладающие исключительно квалификацией судьи (§ 149).

В $\S 151$ и 152 отчетливо подчеркивалось, что прокуроры в своей служебной деятельности независимы от судов и они не могут выполнять действия, входящие в компетенции судей. Запрещен также их служебный надзор за деятельностью судей.

\section{3. Проекты кодификационной комиссии}

\section{1. Проект К. Стефко}

Предложения относительно реформы прокуратуры нашлись лишь в третьем проекте Подкомиссии по устройству судебной системы, автором которого являлся К.Стефко, в предпоследней VII главе под заглавием: Прокуратория государства (ст. 102 - 110). ${ }^{15}$ Само заглавие подсказывает, что автор сознательно обращался, хотя бы по отношению к нменклатуре, к австрийским решениям, однако идею внесения этих положений в отдельный закон, трактующий об устройстве общих судов перенял у немецкого законодателя.

В этом проекте органами Прокуратории государства должны были быть прокуроры и заместители прокуроров, находящиеся в иерархической зависимости от своих вышестоящих начальников и обязаны выполнять их указания (ст. 107). Всех прокуроров и заместителей прокуроров апелляционных судов назначал бы Президент Речи Посполитой, заместителей прокуроров окружных судов - Министр юстиции, как Генеральный прокурор (ст. 102). Могли бы на эти должности назначаться лица, обладающие квалификацией судьи (ст. 103). При Верховном суде функционировали бы: первый прокурор, прокуроры и заместители прокуроров, при аппелляционных же и окружных судах прокуроры и соответствующее количество заместителей прокуроров. Помимо этого, Министр юстиции назначал бы при отдельных повятовых судах заместителей прокуроров окружного суда (ст. 105).

15 Кодификационная комиссия. Подкомиссия по устройству судебной системы. (далее по тексту: KK P.u.s.), т. I, c. $114-115$. 
Прокурор принимал бы участие в процессе как орган правительства с директивой способствовать законному отправлению правосудия с помощью мер, предусмотренных законами о судопроизводстве (ст. 108). Осуществление права надзора и руководства принадлежало бы:

1. Министру юстиции, как Генеральному прокурору государства, по отношению ко всем прокураториям государства в Речи Посполитой в целом;

2. руководителям прокуратории государства: при Верховном суде только по отношению к органам этого учреждения непосредственно ему подчиненным, при апелляционных и окружных судах по отношению ко всем органам прокуратории государства подчиненного им округа.

Главным недостатком проектируемых положений было - по моему мению - отсутствие прозрачного обозначения иерархии, кто, собственно говоря, выполнял бы функции начальников прокуратуры при отдельных судах, а также, следовало бы считать заместителя прокурора представителем органа правительства. Эти вопросы, косвенным образом, обсуждались в ст. 106, но исключительно в отношении их компетенции. Согласно этой статье, руководители прокуратории государства (прокуроры при апелляционных и окружных судах) могли бы предпринимать действия во всех судах подчиненного им округа лично или поручать их выполнение подчиненным им сотрудникам. В последней ст. 110 К. Стефко обратил внимание на раздельность внутренней организации суда и прокуратуры, устанавливая самостоятельные прокурорские конторы.

\section{2. В проекте А. Могильницкого}

В своем проекте ${ }^{16} \mathrm{~A}$. Могильницки по отношению к прокуратуре использовал название „органы и учреждения прокуратуры [urzędy prokuratorskie]” (глава IX, Органы и учреждения прокуратуры [Urzędy prokuratorskie] (ст. 97$103)$ ) склоняясь к решениям, функционирующим в этой области на б. территории аннексированных Россией польских земель. В нормативных правовых актах, издаваемых уже польскими властями с 1918 г. употреблялась именно эта терминология. ${ }^{17}$

А. Могильницки, в отличие от К. Стефко, ввел двухстепенное деление прокуратуры, как В Верховном суде, так и в остальных судах. Он опять сослался на регулирование, действующее на польских землях, благодаря, м.пр. Департаменту юстиции Временного государственного совета. Итак, в свете ст. 97 про-

16 KK P.u.s., t. I, c. 138-139.

17 Во Временных положениях об устройстве судебной системы в королевстве Польском TRS от 1917 г. принято решение относительно публичных органов - прокуроров и подпрокуроров, но уже в марте 1918 г. была издана Инструкция для прокурорских органов и учреждений. 
екта, при Верховном суде должны исполнять служебные обязанности: Первый прокурор и прокуроры, а при апелляционном и окружных судах - прокуроры и заместители прокуроров. Министр юстиции мог бы назначать при отдельных повятовых судах подпрокуроров окружного суда. По его мнению, деление прокуратуры на три степени в Верховном суде не имело никакого основания. „Должно быть - писал в Votach separata -так, как в апелляционном и окружном судах, двухстепенное деление. Действия подпрокуроров, в буквальном смысле, ничем не отличаются от действий прокуроров, за исключением административной стороны и представительства - это принадлежит первому прокурору. Предлагаю ликвидировать должность подпрокуроров при Верховном суде". ${ }^{18}$

Внутренняя организация прокуратуры заключалась бы в иерархической зависимости „нижестоящих” прокуроров от „вышестоящих” (определение, использованное А. Могильницким), а всех - от Министра юстиции, как генерального прокурора. Прокурорские органы при Верховном суде представляли бы собой отдельное целое и не были бы вышестоящей властью по отношению к остальным.

В этом проекте не нашлось места для положений о назначении на должность прокуроров. Несомненно, это было последствием спора между Министром юстиции и Подкомиссией по устройству судебной системы кк, касающегося предметного объема законов: о судоустройстве и статусе судей и прокуроров, кратковременным разрешением которого были решения, принятые 17 ноября 1922 г. во время заседания Подкомитета Специального комитета по организации работ кк РП.

Другие решения, касающиеся организации и деятельности (административной и судебной) органов прокуратуры, то есть осуществления надзора, руководства, заместительства, по отношению к проекту К.Стефко, в принципе не изменились. А. Могильницки в ст. 99 подчеркнул, что каждый прокурор действует от имени всей системы прокурорских органов. Зато он отказался трактовать прокуратуру как орган правительства. Из новых положений заслуживает внимания возможность поручения апелляционным прокурором (по согласованию с председателем этого суда) старшему прокурорскому стажеру постоянно выполнять действия подпрокурора при окружном суде (ст. 101). ${ }^{19}$ кроме этого, А. Могильницки - автор положения о присяжных, предусматривал в составе комиссии, составляющей годовые списки присяжных заседателей для округа 
данного окружного суда, участие прокурора или подпрокурора окружного суда (ст. $81 \S 1)$.

\section{3. В проекте Подкомиссии по устройству судебной системы КК}

В этом проекте положения о прокуратуре были размещены в главе VIII Прокурорские органы и учреждения (ст. 135-143) и являлись практически синтезом предложений К. Стефко и А. Могильницкого. ${ }^{20}$ Члены Подкомиссии не поддались здесь давлению Министра юстиции и вернулись к положениям о назначении и квалификации прокуроров, одобряя, впрочем, по этому вопросу решения К. Стефко. ${ }^{21}$ Прокуроры и подпрокуроры при Верховном и апелляционных судах назначались бы Президентом Речи Посполитой, а подпрокуроры при окружных судах - Министром юстиции (ст. 138). Могли ими быть только (подчеркнуто мной - М.М.) лица, обладающие квалификацией судей (ст. 139). ${ }^{22}$ Вышеуказанное положение унифицировало путь к должности судьи и прокурора. Таким образом, нашли бы здесь аналогично применение такие же условия, каким должны отвечать кандидаты в судьи. Было сохранено трехстепенное деление прокуратуры в Верховном суде. А. Могильницки подверг критике (в Votach separata) институт квази-прокуроров, то есть, лиц, не обладающих квалификацией, соответствующей для того, чтобы занимать должность прокурора, назначенных на определенное время прокурором апелляционного суда исполнять обязанности публичного обвинителя в повятовых судах (ст. 137 абз. 3). ${ }^{23}$ Считал он, что следует этот институт отменить либо сохранить в виде временного положения для б. земель, аннексированных Австрией, до момента введения новой польской уголовной процедуры, которая не предусматривала ,эрзац-прокуроров” такого вида (по крайней мере на этапе работ над ним в секции уголовной процедуры KK). „Австрийский опыт - писал он - доказал, что те заместители прокурора, которые не являются юристами, выполняют свои обязанности очень плохо, поэтому нельзя этот институт оставить, тем более, что можно без него совершенно обойтись". ${ }^{24}$

Сохранено также участие прокурора (без подпрокурора) в окружной комиссии, составляющей годовые списки присяжных заседателей для округа данного окружного суда (ст. 56 b)).

20 KK P.u.s., т. I, c. 160-161.

21 Напомним, что во время заседания Подкомиссии Специального комитета по организации работ кк в ноябре и декабре 1922 г. принято решение включить в проект закона об устройстве судебной системы положения о назначении судей и прокроров. KK P.u.s, Т. І, с. 5.

22 В проекте К. Стефко похожий закон звучал по-другому, не был так однозначен: ст. 103. „Прокурорами и заместителями прокуроров могут быть назначены лица, которые обладают квалификацинй судей”. Разница заключалась исключительно в обороте „могут быть”. Такая формулировка создавала бы возможность допуска на должность лиц без квалификации судей (могут, но не обязательно должны).

24 KK P.u.s., T. I, c. 183. 


\section{4. О прокуратуре в дискуссиях Подкомиссии}

На заседании 27 ноября 1923 г. члены Подкомиссии по устройству судебной системы KK занялись положениями о прокурорских органах и учреждениях, подготовленными в обсуждаемом выше проекте. ${ }^{25}$ По заявлению К. Стефко почти без дискуссии была устранена ст. $135 .{ }^{26} \mathrm{He}$ было её в предыдущих проектах К. Стефко и А. Могильницкого и, по всей вероятности, была устранена из-за излишней неопределенности. Затем В. Прондзынски предложил устранить ст.136, устанавливающую Министра юстиции Генеральным прокурором, так как, по его мнению, пункт 1 ст. 142 „достаточным образом определял должность Министра юстиции". ${ }^{27}$ Поддержали его только Ю. Калужняцки и 3. Сейда. Однако ни один из участников дискуссии не сомневался, что Министр юстиции как Генеральный прокурор исполнял бы одновременно две функции: процессуальную - сам мог бы принимать участие в судебном производстве и административную - он обладал бы правом надзора и руководства по отношению ко всем прокурорским органам в Речи Посполитой в целом. Предложение В. Прондзынского, в конечном счете, не прошло голосования.

В дальнейшей части этого заседания появились два важных постулата, над которыми была проведена длинная и исчерпывающая дискуссия. В первом из них А. Могильницки последовательно высказывался за ликвидацию должности подпрокуроров в Верховном суде, то есть, за двухстепенное деление прокуратуры в этой инстанции. Во втором Ю. Калужняцки предложил, чтобы в апелляционных и земских судах (окружных) работали: первый прокурор, прокуроры и подпрокуроры. Такое решение, по его мнеию, было бы желательным из-за необходиимости существования между шефом прокуратуры и подпрокурорами, старших, более опытных прокуроров. Это предоставляло бы также шанс прокурорам на повышение по службе, в противном случае подпрокуроры охотно уходили бы в органы юстиции. В. Маньковски, поддерживая предложения А. Могильницкого и Ю. Калужняцкого заявил, что в состав прокуратуры Верховного суда должны входить люди „, с особым опытом и образованием” и, что самое главное, со служебным рангом выше прокурора апелляционного суда. Мнения следующих участников дискуссии относительно этих вопросов были, большей частью, противоположные, а спор сосредоточился, главным образом, на объеме действий „шефов” прокуратуры, возможности повышения в должности, номенклатуры (В. Прондзынски предлагал

\footnotetext{
25 KK P.u.s., т. II, c. 110-119.

26 Ст. 135. „Задачей прокурорских органов является надзор за законным отправлением правосудия и способствование этому с помощью мер, предусмотренных законом."

27 Ст. 142. „Правом надзора и руководства обладает: 1. Министр юстиции как генеральный прокурор, по отношению ко всем прокурорским органам в Речи Посполитой в целом [...]." KK P.u.s., т. І, с. 161. Я. Глясс был против устранения ст. 136 утверждая, что „, эта статья содержит общий принцип, дальнейшие последствия которого определяет ст. 142 KK P.u.s., т. І, с. 110.
} 
создание при апелляционном суде постов прокуроров и заместителей прокуроров; при земском суде - прокуроров, заместителей прокуроров и подпрокуроров). Ценную информацию предоставил собравшимся С. Буковецки напоминая, что французский кассационный суд знал три степени прокуроров: procureur général, avocat général и substitut. Окончательно, в результате голосования были поддержаны оба предложения. В связи с тем Я. Глясс редактировал новое содержание абзаца 1 ст. 137 (принятое единогласно), которого текст гласил: „при Верховном суде исполняют служебные обязанности: Первый прокурор и прокуроры Верховного суда, при апелляционных судах - прокуроры и заместители прокуроров апелляционного суда, при земских судах - прокуроры, заместители прокуроров и подпрокуроры земского суда”. Для согласования с другими, уже принятыми законами, установлено, (предложение К. Стефко) что заместителей прокурора будет назначать Президент Речи Посполитой а подпрокуроров - Министр юстиции (ст. 138 проекта). Важным дополнением к этому положению - предложенным В. Прондзынским и утвержденным членами Подкомисси - был абзац 2, регулирующий вопрос по переводу прокуроров на такую же долность при равноправном суде, этим правом обладал бы Министр юстиции.

Очень интересную полемику вызвал своим выступлением Я. Глясс, оглашая фрагмент из своего доклада о роли прокурора как публичного обвинителя. Здесь следует процитировать его в целом, так как была это своего рода кульминационная точка дискуссии, в которой решалась судьба так наз. прокурорской независимости и сталкивались разные мнения относительно места прокуратуры в системе общих судов, базирующие на опыте трех государств, аннексирующих польские территории. Вот и он: „Прокурорские органы находятся в полной иеарархической взаимозависимости, это касается административных действий. Однако на судебном заседании или в уголовном судопроизводстве, где прокурор является стороной в процессе или в гражданском суде, где является важным фактором правильного отправления правосудия, прежде всего, в Верховном суде, прокурор должен обладать полной независимостью, чтобы эффективно принимать участие в отправлении правосудия и противостоять самостоятельной адвокатуре как равный равному. Это возможно лишь тогда , когда не ограниченный никакими инструкциями своих начальников, прокурор будет прислушиваться только к голосу совести и положениям закона, согласно старому принципу: „la plume est serve, mais la parole est libre”. Этот принцип соблюдает устройство системы прокуратуры в родине публичного учреждения - во Франции, но также и в царской России, по старой российской организации судебной системы (ст. 130). Против этого принципа вы- 
ступает австрийское и немецкое законодательство (§ 147 орг. суд. нем. $)^{28}$, делая с представителей публичного учреждения „прокурорских чиновников” во всех действиях зависящих от власти, а также - к сожалению - польский проект". ${ }^{29}$ Итак, автор цитируемого фрагмента из доклада являлся сторонником полной „независимости” прокурора в судопроизводстве - зависящей только от положений закона.

Против этого предложения решительно высказался В. Прондзынски. Он представлял „немецкую” точку зрения и считал, что организация системы прокуратуры должна быть основана на принципе беспрекословного повиновения по отношению к вышестоящим должностным лицам, с которых наивысший - министр - отвечает за деятельность всей прокуратуры. Противником постулата Я. Глясса был также К. Стефко. Он не замечал угрозы ограничения инструкциями прокурора, а если бы такая ситуация произошла - что, скорее всего, случалось бы редко и прежде всего в политическом процессе - то не допускал возможности, чтобы представитель прокуратуры обладал здесь свободой действия. Остальные выступающие (Ю. Калужняцки, А. Могильницки, С. Врублевски, В. Маньковски, С. Буковецки) в принципе поддерживали мнение автора доклада. Ю. Калужняцки заметил, что в австрийском законодательстве не существовал приказ соблюдения прокурором инструкции на судебном разбирательстве; зато А. Могильницки обратил внимание на вероятность возникновения в процессе парадоксальной ситуации (в случае поведения согласно инструкциям начальника), в которой прокурор в своей речи склонялся бы к позиции защиты а в заключении поддерживал бы обвинение. Эту интересную дискуссию прервал достаточно неожиданно представитель Министра юстиции В. Мюллер, внося очень конкретное и одновременно компроммисное предложение, чтобы дополнить обсуждаемую статью 141 проекта следующим содержанием „однако при подаче заявлений на судебном разбирательстве, могут, принимая на себя ответственность, отказаться от выполнения распоряжений, полученных ими в связи с данным делом". Это предложение, поддержанное самим Я. Гляссом, было принято большинством голосов.

Принятие членами Подкомиссии этого решения окончило дальнейшие рассуждения на тему органов и учреждений прокуратуры.

\section{5. О прокурорских органах и учреждениях в окончательном проекте KK}

В Изменениях в проекте об общих судах к проекту VII Подкомиссии по устройству судебной системы, разработанных А. Могильницким, Е.С. Раппа- 
портом и Я. Ямонттом, к главе V. Прокурорские органы и учреждения (ст.108 - 113) были добавлены две новые статьи. ${ }^{30}$ Согласно ст. 110 , способ назначения прокуроров, заместителей прокуроров и подпрокуроров определял бы закон о государственной службе судей и прокуроров. В свете же ст. 112, прокуроры при апелляционном и окружном судах назначали бы на постоянный срок одного или больше заместителей прокуроров или прокуроров для участия в судопроизводстве по делам несовершеннолетних в данном округе. Обе статьи были необходимы из-за факта, что члены кк знали, что ведутся параллельные работы в Минитерстве юстиции над законами: о судах по делам несовершеннолетних и о положении о службе судей и прокуроров. ${ }^{31}$

Во время дискуссии на заседании Подготовительной комиссии комитета по организации работ КK (13 декабря 1924 г.) не была введена в эту часть проекта никакая существенная модификация. Только А. Могильницки изменил свое мнение относительно заместителей прокуроров (при апелляционных и земских судах) и предлагал восстановление этого института по практическим основаниям. Предложение было принято единомышленно. ${ }^{32} \mathrm{~B}$ проекте VIII, то есть, в окончательном проекте кодификационной комиссии были повторены, собственно говоря, все решения содержащиеся в проекте VII Подкомиссии по устройству судебной системы. На этот раз эти положения нашлись в главе VII. Органы и учреждения прокуратуры (ст. 128-134). ${ }^{33}$

\section{4. О прокуратуре в правительственных проектах и в распоряжении}

В правительственный проект закона об общих судах от 1925 г. , по сравнению с окончательным проектом КK, в принципе не были внесены никакие существенные изменения. Заслуживает однако внимания корректировка названий органов прокуратуры, функционирующих при Верховном суде. Итак, в ст. 130 название Первого прокурора было заменено Генеральным прокурором, а заместителей прокуроров - заместителями Генерального прокурора. ${ }^{34}$ В пра-

Там же, с. 190-191.

Проект закона о судах для несовершеннолетних КK приняла 7 декабря 1921 г. а 22 декабря 1921 г. отправила его Министру юстиции. KK P.u.s., t. II, с. 214.

KK P.u.s., т. II, с. 214. В комитете по организации работ KK дискуссия о прокурорских органах вообще не проводилась.

KK P.u.s., т. II, c. 245-246.

Sejm Rzeczypospolitej Polskiej. Издание № 1955. Это обосновывалось следующим образом: „Предлагаемые кодификационной комиссией названия органов прокуратуры, функционирующих при Верховном суде, а именно, Первого прокурора, прокуроров и заместителей прокуроров не вполне соответствуют принципам устройства прокуратуры Верховного суда а также объему труда и квалификации нужной для выполнения этих обязанностей. Хотя работа этих органов по интенсивности и добросовестности есть и должна быть именно такой же, как судей Верховного суда, однако организация Прокуратуры основана на тесной иерархической взаимозависимости. Первый прокурор не является, как это имеет место с судьями, первым между равными; он является вышестоящим чиновником и начальником подчиненных ему органов Прокуратуры; в его руках, как Генерального прокурора, сосредоточивается, в заместительстве 
вительственном проекте закона о судьях и прокурорах общих судов от 1924 г, прокуратуре посвящена часть III в целом (глава IX, ст. 114 - 134). ${ }^{35}$ Этими законами регулировались такие вопросы, как: общие условия, необходимые для назначения на должность прокурора, процедуры номинации, служебные отношения а также права и обязанности. Внимания заслуживает содержание ст. 114: „Прокурор является органом Правительства, он должен стоять на страже конституции, законов и распоряжений Правительства и исполнять свои обязанности с абсолютной бескорыстностью и равной для всех беспристрастностью”. Юридическая комиссия Сейма (куда был направлен этот проект 2 мая 1925 г.) ввела в эту статью важную модификацию. Вместо постановления, что прокурор является органом правительства, эта комиссия сочла необходимым „подчеркнуть роль прокуратуры как блюстителя законности”. ${ }^{36}$

Министра, надзорная власть над органами прокуратуры при высшей судебной инстанции, он должен заботиться об единстве действий подчиненных ему органов и указывать им направление. Поэтому правильнее заменить проектируемое название Первого прокурора, не отражающее сути его действий, названием Генерального прокурора. Структура Верховного суда предусматривает наличие в ним палат (ст. 39). Во главе органов прокуратуры, функционирующих в этих палатах, стоят непосредственные помощники Генерального прокурора, выполняющие в его заместительстве по отношению к остальным органам надзорные и административные действия; для этих органов название заместителей Генерального прокурора будет более адекватным. Так как Прокуратура в Верховном суде не является цепью в иерархии прокурорских органов, толко скорее совещательным и консультационным органом Верховного суда (по проекту закона об уголовном судопроизводстве „Прокуроры при Верховном суде дают объяснения по правовым вопросам"), поэтому может занимать другие служебные должности, в отличие от других прокурорских органов. Принимая это во внимание следовало бы сохранить для других прокурорских органов при Верховном суде название прокуроров при Верховном суде."

35 Sejm Rzeczypospolitej Polskiej. Издание № 1200. „Ст. 115. На должность прокурора может быть назначен тот, кто отвечает требованиям, определенным в ст. 6 и 7 (обладает в полном объеме гражданскими и публичными правами; с безукоризненной репутацией; которому исполнилось 25 лет; владеет польским языком как в устной, так и в письменной форме; окончил университетское юридическое обучение с обязательными в Польше экзаменами; прошел судебную стажировку; сдал судейский экзамен - ст. 6; от обязанности прохождения стажировки и сдачи судейского экзамена были освобождены профессора и доценты юридических наук на польских государственных университетах а также адвокаты - ст. 7);

Ст. $116 \S 1$. Никто не может стать прокурором при этом суде, в котором уже работает судьей или прокурором его родственник четвертой степени родства или свойственник по вторую степень свойства включительно. В случае позднейшего возникновения свойства между судьями и прокурорами одного суда, тот, кто вступил в брак, последствием которого было возникновение свойства, должен быть переведен на другую равностепенную должность.

$\S 2$ от этих постановлений Министр юстиции может отказаться после ознакомления с мнениями прокурора при Апелляционном суде или первого прокурора при Верховном суде;

ст. 117 § 1.Окружных подпрокуроров назначает Министр юстиции среди лиц, которые не менее одного года занимали должность судьи.

§ 2. Всех других прокуроров назначает Президент Речи Посполитой по заявлению Совета министров среди лиц, которые не менее трех лет занимали судейские или прокурорские должности.

§ 3. кандидатов на должности окружных прокуроров и подпрокуроров а также апелляционных подпрокуроров представляет Министру прокурор апелляционного суда, а кандидатов на должности прокуроров и подпрокуроров при Верховном суде - Первый прокурор при Верховном суде. Однако Министр может назначить или предложить на должность другого кандидата.

Ст. 118. § 1. О каждой вакантной должности прокурора Министр объявляет в вестнике законов с указанием даты подачи документов и зявлений претендентов на эту должность.

§ 2. Способ объявления конкурса определит распоряжение Министра юстиции"

36 Sejm Rzeczypospolitej Polskiej. Издание № 2005. Статья эта устанавливала: „Прокурор стоит на страже закона. В своих действиях прокурор подчинен распоряжениям своих вышестоящих властей, руководствуясь равной для всех беспристрастностью". 
Распоряжением Президента РП Закон об устройстве общих судов от 6 февраля 1928 г. на территории II Речи Посполитой была введена организация единой системы прокуратуры. Положения этого закона были, по правде, компиляцией выше обсужденных достижений в этой области как правительства, так и KK. ${ }^{37}$ Прежде всего, не отрицалась представленная в окончательном проекте KK общая концепция устройства прокурорских органов и учреждений. В правительственном проекте закона о судьях и прокурорах эта концепция сохранилась и там, главным образом, все усилия сосредоточились на разработке регулирования положения о прокурорской службе.

Резюмируя рассуждения на тему реформы прокурорских органов и учреждений следует подчеркнуть, что основные принципы, относящиеся к организации и деятельности, обращались в значительной степени к немецкой модели прокуратуры и частично к австрийской. Прокуратура, как государственный орган в области уголовного преследования, по компетенции и по структуре должна быть связана с судебной системой и подчинена Министру юстиции как Генеральному прокурору. Организация прокуратуры опиралась на принципы: централизма, единства и иерархической подчиненности, а способ их действия на принципы: законности, субституции и деволюции. Эту модель одобрили кодификационная комиссия и правительство. Поэтому оба эти органа в равной степени поспособствовали формированию организационно-правовых форм института прокуратуры, окончательно зафиксированных в законе об общих судах [ u.s.p.] от 1928 г. 37 См, шире на эту тему S. Gołąb: Ustrój sądów..., c. 201; A. Czerwiński: Ustrój sądów powszechnych, Lwów
1928, c. 43-45; J. Szuster: Uwagi z powodu ustroju prokuratury, „Gazeta Sądowa Warszawska” 1928, № 27, c. 417-419; S. Zalewski: Prokuratura według projektów ustawy o ustroju sądownictwa i ustawy postępowania karnego, „Gazeta Sądowa Warszawska” 1925, № 24-25, c. 377-390 i 392-396; B. Pohorecki: Udział prokuratora w postępowaniu przed Sądem najwyższym w sprawach cywilnych, „Palestra” 1928, c. 97-100; S. Włodyka: Organizacja wymiaru..., c. 36-44; R.A. Stefański: Prokuratura..., c. 77- 85; S. Śliwiński: Polski proces karny przed sądem powszechnym. Zasady ogólne, Warszawa 1948, c. 300-307. 


\section{WORK OF CODIFICATION COMMISSION OF THE SECOND REPUBLIC ON THE PUBLIC PROSECUTOR'S OFFICE}

The Polish state that regained its independence in November 1918, still operated under the various legal systems (Austrian, German, French, Russian, Hungarian - Spiš and Orava) of the partitioning states. Law organization was the problem of main importance while laying down the foundations of the Second Republic (19181939) and became a heated political and social issue. Reorganizing the law was the role of Polish lawyers of that time. In the Second Republic, the Codification Commission, which was founded especially for this purpose, was in charge of this task.

The Codification Commission of the Republic of Poland was set up by the law passed by Legislative Sejm on 3 June 1919 and was a state body whose task was to "prepare acts of uniform legislation to be binding on all territories belonging to the state." Handling this task pursuant to Law on the system of common courts (including the public prosecutor's office) was the role of the Sub-committee for the structuring of judicial system of the Codification Commission, founded in 1920. Simultaneously, work on this issue was taken up by the Ministry of Justice. Moreover, the lower house of the Polish parliament also played an important role here as it adopted both the March Constitution and the structure of the judicial system and therefore established directions for the Sub-committee and the Ministry's activity.

The ultimate success of the work of the Codification Commission of the Republic of Poland on the reform of the public prosecutor's office was the President's Ordinance Law on the system of common courts of 3 February 1928. Finally, a uniform structure of the public prosecutor's office was introduced on the territory of the Second Republic. Actually, these acts were a compilation of work on this issue of both the government and the Codification Commission.

Key words:

The Second Republic, the Codification Commission of the Republic of Poland, the public prosecutor's office, reforms, the President's Ordinance Law on the system of common courts of 3 February 1928. 